\title{
PROSES INDUKSI SEL DAUN TEMBAKAU (Nicotiana Tabacum)
}

\author{
Teuku Muhammad Zulfikar ${ }^{1,2}$ \\ ${ }^{1}$ Program Doktor IPS Pascasarjana Universitas Syiah Kuala \\ ${ }^{2}$ Fakultas Teknik Universitas Serambi Mekkah Banda Aceh
}

\begin{abstract}
Abstrak-Proses pemeliharaan sel tumbuhan saat ini sudah sering dilakukan, salah satunya adalah proses induksi sel daun tembakau (Nicotiana tabacum). Dari induksi sel daun tembakau dapat dihasilkan berbagai produk, diantaranya adalah quinone. Proses ini banyak dilakukan karena disamping produk yang dihasilkan lebih murni, keutuhan sifat quinone juga dapat terjaga. Selain itu bahan baku yang digunakan tersedia dengan cukup. Suplai oksigen yang rendah sangat efektif untuk meningkatkan produksi quinone. Untuk mengurangi suplai oksigen yang masuk dapat digunakan asam askorbat sebagai anti oksidan karena senyawa ini mudah bereaksi dengan oksigen. Callus dipindahkan ke medium cair yang telah ditambahkan dengan asam askorbat. Pertumbuhan sel dalam medium cair diamati melalui berat sel segar yang diperoleh, dimana berat sel segar naik dengan naiknya konsentrasi asam askorbat dan mencapai optimum pada konsentrasi asam $0,50 \mathrm{mg} / \mathrm{l}$. Kandungan quinone ditentukan dengan menggunakan alat HPCL, dimana kandungan quinone yang paling banyak diperoleh pada konsentrasi asam askorbat $0,50 \mathrm{mg} / \mathrm{l}$ yaitu sebesar $0,4030 \mathrm{ppm}$.
\end{abstract}

Kata kunci: Induksi Sel, Daun Tembakau dan Quinone

\section{Pendahuluan}

\subsection{Latar Belakang}

Pembangunan jangka panjang tahap II yang dititikberatkan pada sektor industri merupakan salah satu pemicu berkembangnya daerah-daerah industri di Indonesia. Begitu juga dengan perkembangan teknologi yang semakin pesat, tidak terlepas dengan pemanfaatan bioteknologi.Dimana pemanfaatan bioteknologi tersebut juga mengalami kemajuan yang cukup pesat. Salah satunya adalah timbulnya pengetahuan mengenai komposisi kimiawi dan caracara zat kimia berinteraksi untuk menciptakan dasar dari suatu kehidupan yang disebut sel.

Penelitian secara nyata dari perkembangan sel muncul kira-kira satu abad yang lalu. Arnold pertama kali menunjukkan pada tahun 1880 yang menyelidiki tentang sel hewan. Tak lama kemudian diikuti oleh Habertlandt, dan ia melaporkan bahwa sel tumbuhan yang berasal dari suatu varietas dapat diperbaharui apabila dimasukkan dalam larutan yang mengandung zat nutrien.

Salah satu penemuan penting dalam penelitian mengenai pertumbuhan sel dilakukan oleh Harrison pada tahun 1907. Kemudian dikuatkan oleh Carrel pada tahun 1913, yaitu tentang penelitian sebuah kultur, dimana jika sepotong jaringan tumbuhan direndam dalam getah bening maka dari hasil penelitian dapat diketahui bahwa spesies baru dapat dikembangkan. Mereka menarik kesimpulan bahwa sebagian besar spesies yang hidup dalam kultur tersebut berkembang dengan pesat. Perkembangannya tidak hanya tergantung pada garam-garam organik tetapi juga pada unsur organik lengkap.

Aplikasi pertama dari perkembangan induksi sel tumbuhan dalam menghasilkan suatu produk terjadi pada tahun 1970-an dengan pengurangan enzim 3-5-Phospodiesterase yang berasal dari daun tembakau (Nicotiana tabacum). Pada perkembangan selanjutnya induksi sel tidak hanya dilakukan dengan memanfaatkan bagian jaringan luar saja tetapi juga jaringan bagian dalam (Speir, R, E, 1988).

Pemeliharaan sel tumbuhan yang banyak dilakukan saat ini adalah pemeliharaan sel tembakau (Nicotiana tabacum). Dari induksi sel daun tembakau dapat menghasilkan beberapa produk, diantaranya adalah quinone. Quinone sering dimanfaatkan dlam industri farmasi dan industri makanan untuk pembuatan zat warna.

Pada induksi sel, jaringan yang sering digunakan adalah akar, batang dan daun. Jaringan yang akan diinduksi diambil dan ditempatkan pada sebuah wadah yang telah diisi zat nutrien dan ditempatkan pada kondisi yang sesuai bagi pertumbuhan sel tersebut (Kurz and Constabel, 1979). Produk yang dihasilkan dari induksi sel tumbuhan ini terdapat dalam beberapa bidang diantaranya: makanan, kosmetik, agrikultur dan farmasi. Jenis tumbuhan serta produk yang dihasilkan dapat dilihat pada Tabel 1.1. berikut ini: 


\begin{tabular}{|l|l|l|l|}
\hline \multicolumn{1}{|c|}{ Produk } & Tumbuhan & Aktifitas & Industri \\
\hline Anthocyanins & Populus nigra & Pigmen & Makanan \\
Attar & Rossa SP & Parfum & Kosmetik \\
Digoxin & Papaver SP & Analgesik & Farmasi \\
Diosgenin & Digitalis LT & Cardiatonic & Farmasi \\
Jasmine & Diosscorea DL & Antifertil & Farmasi \\
Quinone & Jasminum SP & Parfum & Kosmetik \\
Pyrethrin & Cinchona LG & Anti Malaria & Farmasi \\
\hline
\end{tabular}

Sumber: Spier and Fowler, 1988

\section{I.2. Perumusan Masalah}

Dari uraian diatas memberi petunjuk dan menjelaskan betapa besar manfaat induksi sel bagi perkembangan industri di masa yang akan dating. Mengingat manfaat yang begitu penting, maka perlu dilakukan suatu usaha induksi dan pemeliharaan sel yang semaksimal mungkin, sehingga dapat dihasilkan produk yang lebih banyak.

\section{I.3. Tujuan Penelitian}

Tujuan penelitian ini adalah untuk melihat dan mempelajari pengaruh dari beberapa variable pada induksi sel daun tembakau (Nicotiana tabacum). Hasil penelitian skala laboratorium ini diharapkan dapat memberikan informasi yang dapat dimanfaatkan untuk penelitian lebih lanjut tentang induksi sel.

\section{Metode Penelitian}

\subsection{Persiapan Alat dan Bahan}

Alat dan bahan yang diperlukan untuk melakukan induksi sel adalah sebagai berikut:

a. Alat-alat yang digunakan:

1. Erlenmeyer

2. Timbangan listrik

3. Autoclave

4. Beaker glass

5. Pipet volume

6. Cawan Petri

7. Pisau

8. Pinset

9. Kertas saring

10. Aluminium foil

11. Lampu spiritus

12. Karet penghisap

13. Alat HPLC

14. Pompa penghisap

b. Bahan-bahan yang digunakan: 

1. Daun tembakau segar
2. Aquades
3. Sukrosa
4. Thiamine- $\mathrm{HCl}$
5. Myo-inositol
6. Ethanol $80 \%$
7. 2,4-Dichloro phenoxyacetid Acid
8. $\mathrm{NaOH} 0,5 \mathrm{~N}$
9. Asam askorbat
10. Spiritus

\subsection{Induksi dan Kultivasi Sel Tumbuhan}

Persiapan yang dilakukan untuk terjadinya induksi dan kultivasi sel pada daun tembakau adalah sebagai berikut:

1. Persiapan daun tembakau

2. Persiapan media

3. Tahap pertumbuhan callus

4. Tahap pemeliharaan sel

\subsection{Persiapan Daun Tembakau}

1. Diambil daun tembakau segar

2. Disterilkan dengan menggunakan ethanol $80 \%$ dan kemudian dicuci dengan air

3. Disiapkan pisau yang tajam dan telah disterilkan

4. Daun tembakau dipotong-potong dengan ukuran $0,5 \times 0,5 \mathrm{~cm}$

\subsection{Persiapan Media}

1. Disiapkan cawan petri yang steril

2. Disiapkan larutan yang mengandung:

- $30 \mathrm{~g} / \mathrm{l}$ Sukrosa

- 1,0 mg/l Thiamine-HCl

- $100 \mathrm{mg} / \mathrm{l}$ Myo-Inositol

- 0,2 mg/1 2,4-Dichloro Phenoaxiacetic Acid

- 0,1 , 0,3, 0,5, 0,7 dan 0,9 mg/l asam askorbat

- Aquades 1 liter

3. Usahakan $\mathrm{pH}$ antara 5,5 - 6,0 dengan menambahkan $0,5 \mathrm{~N} \mathrm{NaOH}$ secara hati-hati

4. Pipet larutan ke dalam 10 buah cawan petri (@5ml)

5. Cawan petri dibungkus dengan aluminium foil dan dipanaskan dalam autoclave selama 15 menit pada temperature $115^{\circ} \mathrm{C}$ dan kemudian didinginkan.

\subsection{Tahap Pertumbuhan Sel}

1. Media yang telah disiapkan dimasukkan dalam dua buah kotak, masing-masing berisi 5 buah cawan petri.

2. Daun tembakau yang telah dipotong-potong dimasukkan ke dalam media dan kotak ditutup dengan plastic transparan.

3. Kotak yang satu ditutup dengan kain hitam dan yang lain dibiarkan.

4. Diamati setiap perubahan yang terjadi sampai terbentuk callus selama lebih kurang 25 hari.

\subsection{Tahap Pemecahan Dinding Sel}

Media yang telah diisi nutrien dan daun tembakau diamati setiap tiga hari sekali. Setelah beberapa hari akan terlihat disekitar daun tembakau sel berbentuk lender berwarna putih dan kental. Dengan penambahan asam askorbat, dinding sel akan terputus dan pecah sehingga mengganggu daya tahan protoplast. Dengan pecahnya dinding sel tersebut akan mengeluarkan quinone yang merupakan produk intra selular sel.

\subsection{Tahap Pemeliharaan Sel}

1. Disiapkan 10 buah erlenmeyer dan diisi dengan larutan seperti yang diisikan ke dalam cawan petri (@100 $\mathrm{ml})$, kemudian disterilkan.

2. Callus yang telah terbentuk dipindahkan ke dalam erlenmeyer. 
3. Erlenmeyer ditempatkan diatas shaker dan digoyang pada $100 \mathrm{rpm}$.

4. Diamati setiap hari perubahan yang terjadi selama 7 hari.

\section{Hasil Dan Pembahasan}

\subsection{Pengaruh Cahaya Terhadap Pertumbuhan Sel}

Secara alamiah tumbuhan memerlukan cahaya matahari untuk melakukan fotosintesis. Semakin banyak intensitas cahaya yang diterima, maka metabolism tumbuhan akan semakin baik, begitu juga sebaliknya bila cahaya yang diterima sangat sedikit metabolismen tumbuhan akan terganggu dan dapat menyebabkan tumbuhan menjadi layu bahkan mati. Tetapi pada induksi sel malah terjadi sebaliknya.

Gambar 3.1. menunjukkan bahwa perkembangan sel daun tembakau yang ditempatkan pada ruang gelap mengalami pertumbuhan agak cepat dibandingkan dengan pertumbuhan sel daun tembakau yang ditempatkan pada ruang terang. Hal ini terjadi karena pada ruang terang intensitas cahaya yang diterima media terlalu banyak sehingga akan mempercepat terjadinya oksidasi terhadap asam askorbat yang ditambahkan ke dalam media, akibatnya ketersediaan oksigen di dalam media menjadi semakin berkurang dan dengan sendirinya akan mempengaruhi pertumbuhan sel.

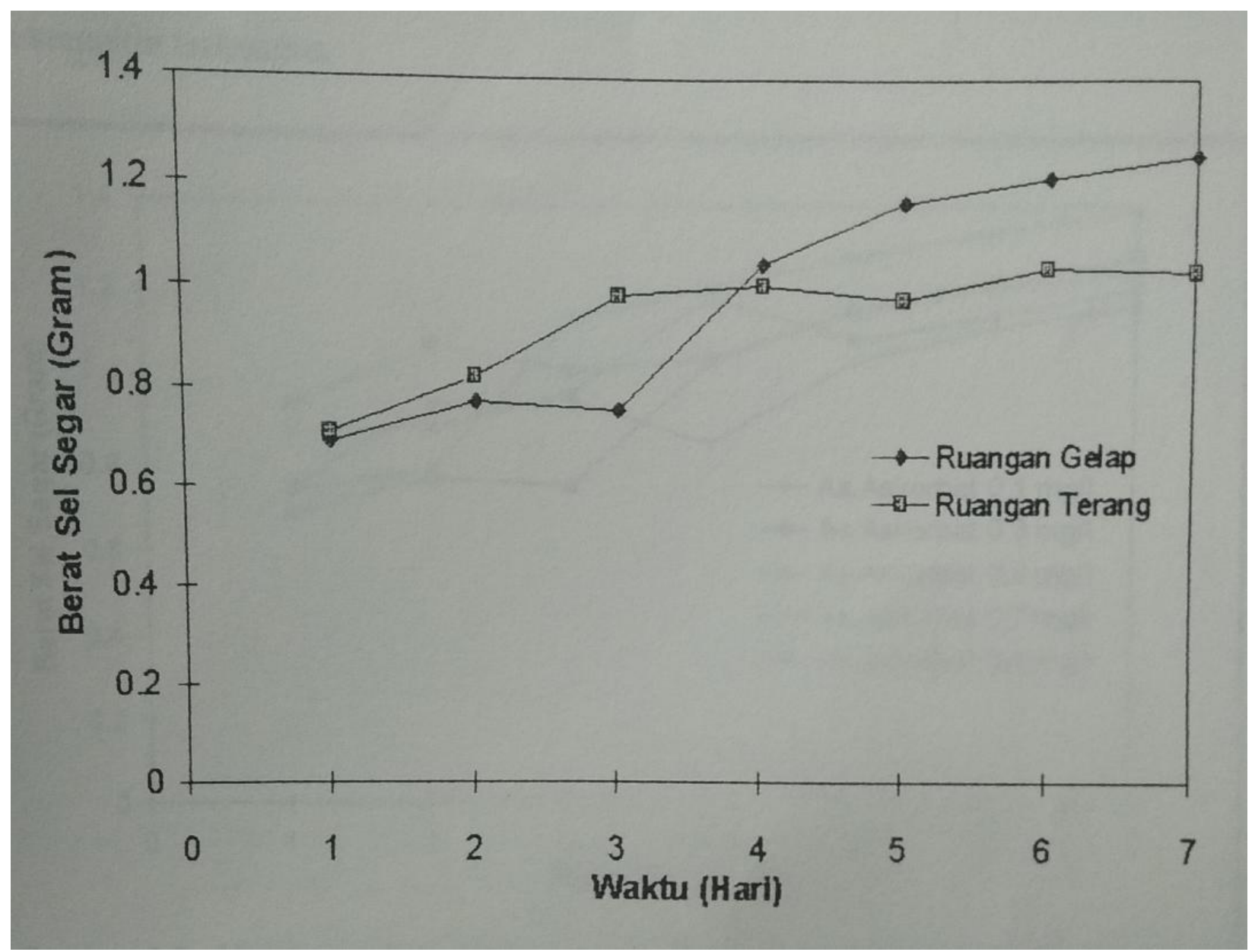

Gambar 3.1. Grafik hubungan laju pertumbuhan sel dengan waktu pada kondisi cahaya yang berbeda.

\subsection{PengaruhAsam Askorbat Terhadap Perkembangan Sel}

Dari hasil pengamatan, pertumbuhan sel mulai terjadi pada hari ke tujuh setelah inokulasi yang disebut dengan callus. Callus tersebut kemudian dipindahkan ke media cair yang telah ditambah asam askorbat dengan konsentrasi 
tertentu dalam erlenmeyer. Setelah satu hari sampel dari erlenmeyer diambil dan dianalisa kandungan sel segar. Gambar 3.2. memperlihatkan pertumbuhan sel meningkat seiring dengan bertambahnya waktu. Semakin tinggi konsentrasi asam askorbat pertumbuhan sel cenderung untuk menurun. Hal ini terjadi karena asam askorbat yang ditambahkan ke dalam media pemeliharaan bereaksi dengan oksigen, sehingga laju absorbsi oksigen oleh sel untuk pertumbuhannya menjadi berkurang. Semakin meningkat jumlah anti oksidan yang ditambahkan maka laju absorbsi oksigen oleh sel akan semakin kecil, akibatnya pertumbuhan sel akan semakin meningkat.

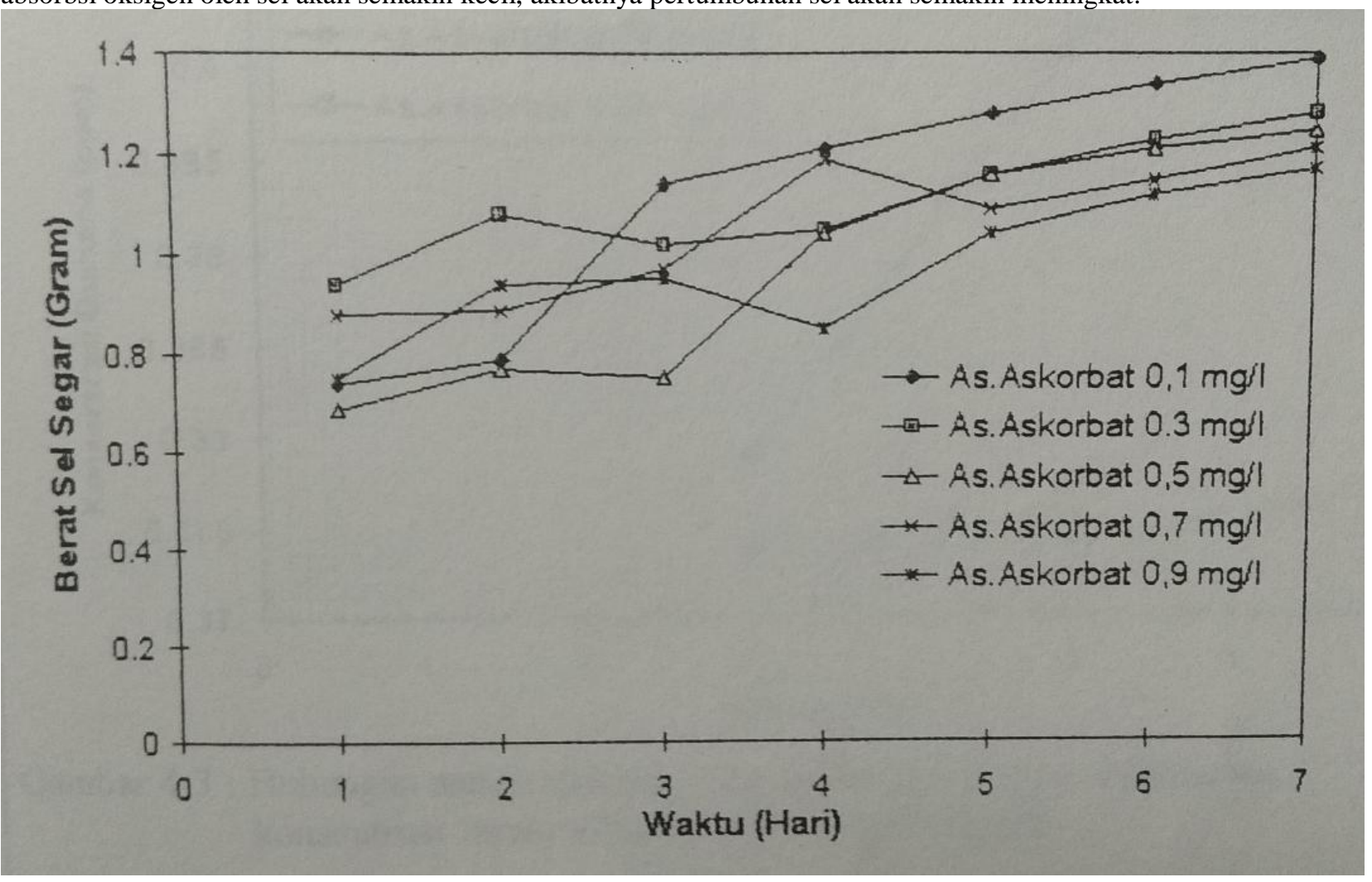

Gambar 3.2. Hubungan pertumbuhan sel dengan waktu pada berbagai konsentrasi asam askorbat (mulai dari 0,1 $\mathrm{mg} / \mathrm{l}$ sampai $0,9 \mathrm{mg} / \mathrm{l}$ ) pada ruang gelap.

\subsection{Pengaruh Asam Askorbat Terhadap Produksi Quinone}

Anti oksidan yang digunakan pada penelitian ini adalah asam askorbat yang berguna untuk mempengaruhi proses sekresi quinone dan menghambat terjadinya oksidasi terhadap quinone yang dihasilkan. Hubungan antara waktu dan quinone yang dihasilkan pada konsentrasi asam askorbat $0,70 \mathrm{mg} / \mathrm{lt}$ dan $0,90 \mathrm{mg} / \mathrm{lt}$ disajikan dalam Gambar 3.3.

Semakin tinggi konsentrasi asam askorbat yang digunakan, konsentrasi quinone yang dihasilkan akan semakin tinggi. Hal ini dikarenakan oksigen yang diabsorbsi oleh media terlebih dahulu akan mengoksidasi asam askorbat, sehingga oksigen yang digunakan untuk pertumbuhan sel menjadi sangat berkurang. Untuk mempertahankan kelangsungan hidupnya sel mengeluarkan quinone sebagai reaksi dari kekurangan oksigen tersebut. 


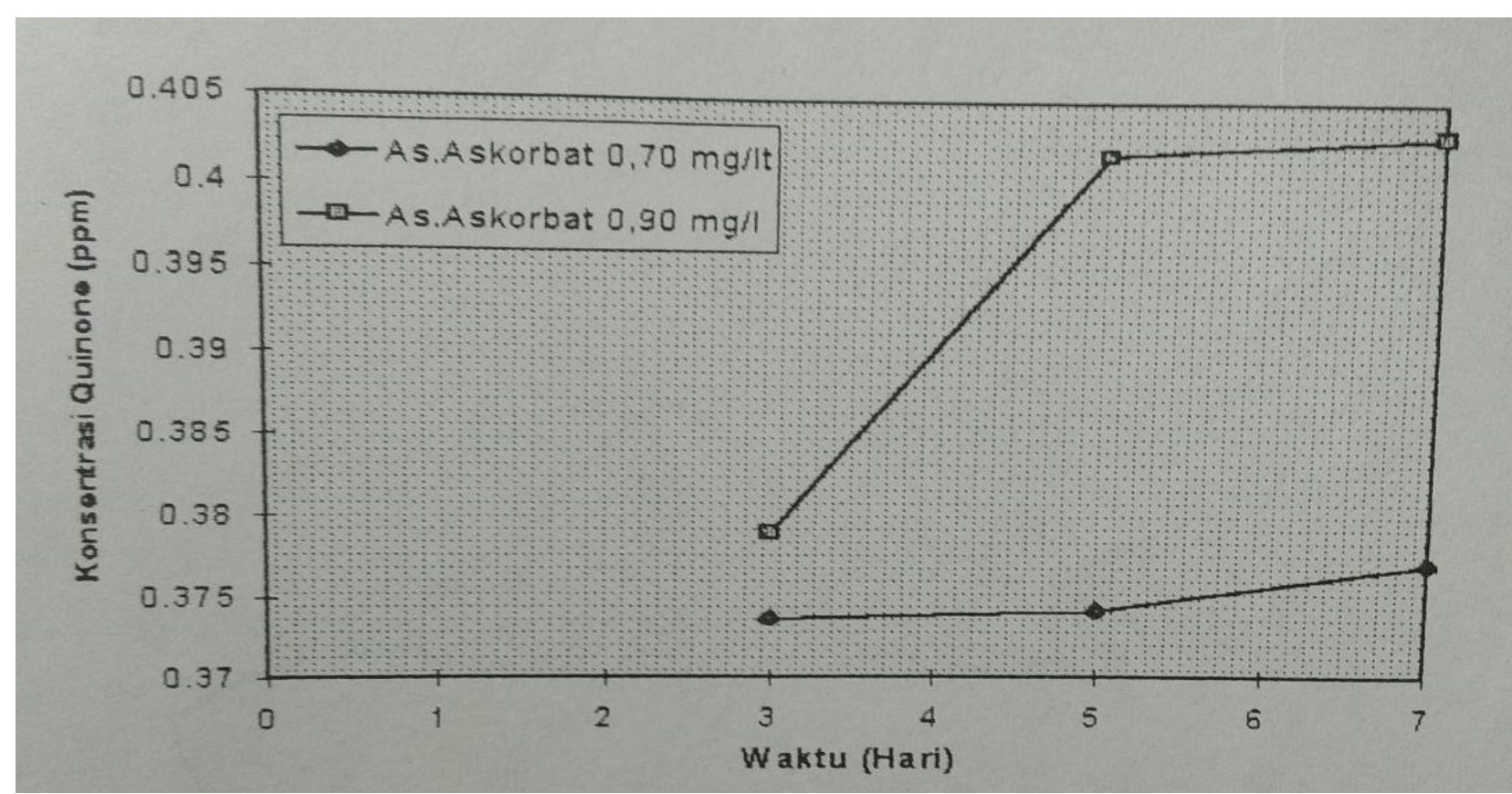

Gambar 3.3. Hubungan antara quinone yang dihasilkan dengan waktu pada konsentrasi asam askorbat 0,70 dan $0,90 \mathrm{mg} / \mathrm{lt}$

\section{Kesimpulan}

1. Inokulum sel tembakau (Nicotiana tabacum) yang ditempatkan pada tempat gelap mengalami pertumbuhan yang lebih cepat dibandingkan dengan yang ditempatkan pada ruang terang.

2. Pada penambahan asam askorbat dari $0,1 \mathrm{mg} / \mathrm{lt}$ sampai $0,9 \mathrm{mg} / \mathrm{lt}$, semakin tinggi konsentrasi asam askorbat yang ditambahkan ke dalam media, perkembangan sel semakin lambat.

3. Semakin kecil ketersediaan oksigen dalam media, maka konsentrasi quinone yang dihasilkan akan semakin meningkat.

Mengingat akan pentingnya pemanfaatan induksi sel untuk menghasilkan suatu produk tertentu yang tidak dapat disintesa dengan cara yang mudah dan murah, maka perlu dilakukan penelitian lebih lanjut untuk mendapatkan suatu kondisi yang cocok bagi pertumbuhan sel dan dapat menghasilkan produk yang lebih banyak.

\section{Daftar Pustaka}

[1] Ikeda, T, 1976, "Effects of Nutritional Factors on the Formation of Ubiquinone by Tobacco Plant Cells in Suspension Culture", Agriculture Biological Chemistry, Vol. 40 (9), 1765 - 1770.

[2] Ikeda, T, 1976, "Effects of Ubiquinone by Tobacco Plant Cells in Suspension Culture", Agriculture Biological Chemistry, Vol. 15, 568 - 569, England.

[3] Ikeda, T, 1981, "Selection of Cultured Tobacco Cell Strains Producing High Level of Ubiquinone 10 by a Cell Cloning Technique”, Agriculture Biological Chemistry, Vol 45 (7), 1627 - 1633.

[4] Lee, D dan Barbara, A, M, 1994, "Adenine Salvage Activity During Callus Induction and Plant Growth", Physiologia Plantarum, Vol. 90, 739 - 734, Denmark.

[5] Lee, M, J, 1992, “Biochemical Engineering”, Prentice Hall, International Series, New Jersey.

[6] Shuler, M, L, dan Kargi, F, 1992, "Bioprocess Engineering Basic Concepts", Prentice Hall International, Inc., Houston.

[7] Spier, R, E, dan Fowler, M, W, 1988, "Animal and Plant Cell Cultures", Comprehensive Bioteknologi, Vol. $1,301-329$. 